\title{
A Shift or Priority? An Afrocentric Analysis of Zuma's Foreign Policy towards China
}

\section{Dominic Maphaka}

Department of Cultural and Political Studies

University of Limpopo, South Africa
Article DOI:

https://doi.org/10.35293/srsa.v42i2.75

\section{Abstract}

Zuma's ascendancy to the South African Presidency coincided with the lingering global economic crisis of 2007-2009, which affected many of the Western economies. By this time, China experienced a rapid economic growth and became a potential partner for commodities exporting countries like South Africa. As such, it became a potential partner in the face of declining commodity demand from the West. Against this background, Zuma deepened South Africa's ties with China to rescue the domestic economy. China has since received much attention in Zuma's administration resulted in many scholars emanating from International Relations and other cognate academic disciplines and members of the media describing the move as a shift in South Africa's foreign policy. This article employs Afrocentricity as an alternative theoretical framework to interrogate the question as to whether closer ties between the two countries marked a shift or Zuma prioritised China. Methodologically, this is a desktop article that relied on secondary data and employed an Afrocentric qualitative research methodology to establish whether the deepening relations led to a shift in South Africa's foreign policy or China received priority in Zuma's administration.

Keywords: Afrocentricity; South Africa; Foreign Policy; Zuma; China; Shift. 


\section{Introduction}

South Africa's democratic dispensation led to a shift in both domestic and foreign policy. The newly democratic elected African National Congress (ANC) led government redefined South Africa's image after years of isolation under apartheid regime. As such, South African joined or rejoined various international organisations (IOs).The democratic dispensation also saw the country establishing and re-establishing bilateral relations with other states. Included here was the formalisation of relations with China in 1998 (Chiyemura 2014; Moinogu 2015; Asuelime 2018a). The relationship with China has since been upgraded from Strategic Partnership in 2004 to a Comprehensive Strategic Partnership in 2010, which marked the deepening of South Africa-China relations under Zuma's administration (Naidu 2015; Alden and Wu 2016; Mhaka and Jeke 2018). With the West being hit hard by the global economic crisis, China became an alternative partner to commodity exporting countries like South Africa and has since received much attention under Zuma's administration (Cilliers 2017). This has resulted in many scholars emanating from International Relations and other cognate academic disciplines and members of the media describing the move as a shift in South Africa's foreign policy. The article employs Afrocentricity to interrogate the question as to whether closer ties between the two countries marked a shift or Zuma prioritised China. Methodologically, this is a desktop article employing Afrocentric qualitative research methodology as articulated by Asante (2007), Mazama (2001), Ntseane (2011) and Schreiber (2000) to establish whether the relations led to a shift in South Africa's foreign policy or China was just prioritised by Zuma's administration. Data analysis is guided by the Afrocentric principles of location/center, relocation, grounding and orientation (Reviere 2001; Mkabela 2005; Shai 2016). As a result, it is centered and grounded on African interests, culture, values, religion and history.

Guided by the foregoing principles, the article analyses South Africa's foreign policy towards China, from Mandela to Zuma's administration, to determine whether the latter President introduced a policy shift in favour of Beijing or China was just accorded an apex priority. This paper is divided into five sections. The first section expounds Afrocentricity an alternative theoretical framework adopted for the study. This is followed by the section that analyses South AfricaChina relations at the bilateral level. In the subsequent section, the paper analyses 
South Africa-China relations at the multilateral level. The fourth section answer a question as to whether Zuma's foreign policy towards China marked a shift in the country's policy or the latter country received a priority. The last part of the paper provides the conclusion and findings.

\section{An Afrocentric Lens of Analysis}

Afrocentricity derives from the Pan-Africanist movement, writers and leaders. Asante is credited to be the founder of Afrocentricity. He adopted and complemented the works of writers who predated him in his publications titled Afrocentricity: The Theory of Social Change; Kemet, Afrocentricity and Knowledge, and The Afrocentric Idea. The principles of Afrocentricity are cultural centeredness, paradigmatic pluralism, liberation and cultural agency (Schreiber 2000; Asante 2007; Ntseane 2011). The central argument of Afrocentricity is that an African phenomenon or communities cannot be understood when studied from outside. It requires the researcher to be positioned in African experiences in order to attain valid knowledge about an African phenomenon. The center denotes a location/place/position. Unlike Eurocentric studies on African phenomenon, Afrocentricity stresses that African culture, ideals, values and history should provide a basis for any study conducted on African phenomenon or communities. The tenet of centeredness covers a belief that African economies are consigned to the margins of the global economy. Thus, Africans should reclaim their culture, ideals, values, history and interests to relocate their economies from the margins to the center of the global economy (Schreiber 2000; Mazama 2001).

Afrocentricity does not reject the use of more theories in multicultural studies. It rejects Eurocentric ethnocentricity in non-Europeans. In other words, non-Europeans including Africans should be studied from their perspective. The perspective for each nation should be used equally to enhance coexistence in multicultural studies. Thus, Eurocentricity is not supreme but a perspective among others (Schreiber 2000; Ntseane 2011). The main objective of Afrocentricity is to re-center, revive, and liberate African societies. Included here is the African history, views on epistemology, ontology, axiology, and the liberation of minds. The major argument of Afrocentrists is that Greek civilisation predated African civilisation. In spite of this, it is only Greek civilisation that is credited as the cradle of civilisation, history, knowledge, and development. As such, Africa should 
be acknowledged for her contribution to the world's knowledge, particularly Greek civilisation (Schreiber 2000; Asante 2007). The adoption of Afrocentricity is informed by the author's positionality as an African in South Africa. With this, the author shifts the locus of reason by using Afrocentricity as an alternative theoretical framework to the predominantly Eurocentric discourse of Zuma's foreign policy towards China.

\section{The Bilateral Relations of South Africa-China}

The existing literature traces formal relations between South Africa and China to 1998 when the two countries established diplomatic ties (Benyi 2017). Naidu (2015), Alden and Wu (2016), Mhaka and Jeke (2018) assert that the two countries have since 1998 signed a number of agreements. Among others, Pretoria Declaration was signed in 2000 to formalise South Africa-China relations. The Declaration led to the formation of Bi-national Commission in 2001. The relationship was upgraded to a Strategic Partnership in 2004 and the two countries signed a Programme for Deepening Strategic Partnership in 2006. South AfricaChina relationship was elevated to a Comprehensive Strategic Partnership during Zuma's first state visit to China in 2010. Strategic Partnership refers to a broad diplomatic action which entails cooperation in areas such as political, economic and cultural matters at the bilateral, regional and international arena. On the other hand, a Comprehensive Strategic Partnership refers to a cooperation that is all-dimensional, wide-ranging and multilayered. It incorporates cooperation in economy, science, technology, political and cultural matter, has both bilateral and multilateral levels, and is undertaken by governmental and non-governmental organisations (Jin and Zhongping 2014)

The two countries also signed a Joint Inter-Ministerial Working Group (JIMWG) agreement in 2013, through which they commit to hold bi-annual meetings between their ministers (Anthony, Tembe and Gull 2015; Cilliers 2017). They further signed a number of agreements in 2014. Included here is a 5-10 Year Strategic Programme on Cooperation in areas such as mutual trust in political and strategic coordination, trade and economic cooperation that is mutually beneficial. The 5-10 Year Strategic Programme on Cooperation also covers people-to-people exchanges, cooperation on African and global affairs as well as in BRICS forum. They undertook to enhance economic cooperation 
in trade and investment between the South African Department of Trade and Industry (DTI) and Chinese Ministry of Commerce. Other agreements signed in 2014 are the Action Plan on Agriculture Cooperation, Protocols of phytosanitary requirements through which China commit to import South African maize meal and apple fruit, and South Africa undertook to import dates from the former country (Naidu 2015; Mhaka and Jeke 2018). In human resource development, China undertook to increase short-term courses and raise training programmes granted to South Africans for a period of 2015-2020. It also commits to complement and support South Africa's industrialisation efforts by investing in areas such as science and technology, industrial parks and railway parks (Naidu 2015). South Africa and China further signed 26 agreements accounted to R94 billion in 2015 with an intention to address imbalanced trade among other things (Asuelime 2018b).

The South African DTI signed a Memorandum of Understanding (MOU) with the Chinese Ministry of Commerce in 2016. Through such MOU, the two parties commit to cooperate on Special Economic Zones (SEZs) and Industrial Parks. These developments have saw the South African government sending officials from State-Owned Enterprises (SOE) to study Chinese development model in an effort to accelerate the country's industrialisation. For example, the officials were sent to learn from the Chinese SEZs and evaluate the possible establishment of such Zones in South Africa (Grimm et al 2014). The DTI also signed the Framework of Agreement with China's National Development and Reform Commission to cooperate on Production Capacity (DIRCO 2017). Apart from increased state-state relations, Zuma's administration deepened partyto-party relations with the Chinese Communist party (CCP). This has saw the ANC National Executive Committee being dispatched to Beijing for three weeks training on management and organisational matters (Alden and Wu 2016).

As indicated earlier, China has since the global economic crisis became South Africa's largest trading partner. South African exports to Western countries declined by $32 \%$ in 2009 due to the global economic crisis (Notshulwana 2012; Mhaka and Jeke 2018). Mazenda (2016b) shares the same sentiment that, the South African exports to China increased largely in a period of 2007-2009, at the time trade with former partners declined due to global economic crisis. It is within this context that China enabled South Africa to weather the effects brought by the global economic crisis. Two-way trade reached $\mathrm{R} 85$ billion in 
2011 and South Africa accounted to 25\% of China's trade with the continent in the same period (Yang 2012; Alden and Wu 2014). Two-way trade rose from R205 billion in 2012 to R270 billion in 2014, a record of 32\% increase (Asuelime 2018b; Mhaka and Jeke 2018). South Africa's trade with China accounted to R262 billion in 2015 (Anthony et al 2015).

While the ANC led government deepened South Africa's relations with China, the Congress of South African Trade Unions (COSATU) has been critical against unequal trade patterns between the two countries (Alden and Wu 2016). It saw China as a neo-colonial partner posing threat to the country's economic growth (Marthoz 2012). In agreement, Mhaka and Jeke (2018) assert that, since 2009 the trade patterns have been in favour of China. About 90\% of South African exports to China were constituted by unprocessed products in 2014 . China imports the South African minerals to sustain its booming economy. On the other hand, value-added products produced from such minerals are exported to South Africa.

Monareng (2016) notes that South Africa's trade deficit with China rose from R36 billion to R38 billion in 2013. In the same vein, Mhaka and Jeke (2018) submit that South African exports to China accounted to $\$ 8.7$ billion and imports from China reached $\$ 15.4$ billion in 2014. Equally, Mazenda (2016a) postulates that the booming economies of BRICS (Brazil, Russia, India, China and South Africa) countries and their rising commodity demand spurred South Africa to shift trade in their favour. He went on to mention that South Africa's trade with China rose largely, but Tshwane's -The Capital City and Administrative hub of South Africa-exports were not enough to reduce imbalance trade. The data drawn by Mpungose (2018) from the South African Revenue Service (SARS) indicates that, South Africa had a trade deficit of $9.2 \%$ with China in 2017. Trade remained imbalanced and not in keeping with the principle of win-win cooperation.

China's rapid economic growth has also led to the de-industrialisation of the South African economy and huge job losses (Anthony et al 2015). A number of South African steel enterprises were de-industrialised by imports from China and other countries in 2015, and Chinese steel reached half of such imports. The overproduction in China prompted the relocation of industries to South Africa. As a result, the South African companies, Evraz Highveld Steel and Vanadium was bailed out and Tata Steel's Operation in Richards Bay was auctioned off. In addition, small steel enterprises, namely Alert Steel and Duro Pressings were 
liquidated. These developments sparked calls for protectionist measures and the South African government imposed tariffs in 2016 (Neethling 2017; Yu 2018). To add on the foregoing arguments, Soko and Qobo (2016) says that, the rising labour costs at home, make China to relocate its manufacturing companies to cheaper destinations.

On the other hand, Chinese aid to South Africa undermined the transfer of skills and technology. A case in point, is the South African Agricultural Technology Demonstration Centre (SAATDC). During the construction of this project, engineers and artisans were sourced from China. The role of the South African work force was limited to providing general labour and other support services (Tshetlo and Naidoo 2015). In the context of Afrocentric theoretical framework adopted for this paper, trade with China perpetuates the economic dislocation of the country as it was the case with former colonisers. South Africa remains a net exporter of raw materials in exchange for value-added manufactured goods. Its trade with China is also dislocating the domestic work force to the margins of the national wealth. In other words, China benefit its nationals at the expense of their South African counterparts. South Africa-China relations could be described as a diversified form of dependency, underdevelopment and domination with China being at the apex position as the world's second economy and South Africa consigned at the margins as the developing country.

\section{South Africa-China Relations in Multilateral Contexts}

At the multilateral level, the two countries cooperate in international forums and institutions such as the Forum on China-Africa Cooperation (FOCAC), BRICS, Group of Twenty (G20), and United Nations (UN) etcetera (Mhaka and Jeke 2018). Through the 2010 Comprehensive Strategic Partnership of the Beijing Declaration, South Africa and China commit to cooperate at the UN and other multilateral forums (Alden and Wu 2016; Monareng 2016; Anthony et al 2015). For example, on issues of global governance reform, South Africa and China together with other BRICS partners established the New BRICS Development Bank (NDB) to facilitate the reform of international financial institutions (IFIs) such as the International Monetary Fund (IMF) and World Bank (WB) (Naidu 2015; Chiyemura 2014).

Against this background, Zuma used BRICS platform to complement the 
South African efforts at calling for the reform of global governance (Naidu 2015). In agreement, Asuelime (2018b) says that collaboration with BRICS add weight on South Africa's voice relative to unitary call for global reform. In the same line of arguments, Gumede (2014) notes that for Zuma, BRICS countries remained strategic partners for South Africa in lobbying for the reform of the world trade, economic and political system. Drawing from Afrocentricity, China together with other BRICS partners complement South Africa's efforts at relocating from the margins to the centre of global economic governance. It calls for a shift from global coloniality, which is largely premised on the Western domination and exploitation of global economic and governance institutions. In essence, BRICS complements South Africa's Afrocentric foreign policy of a reformed global system accompanied by the improvement in African representation.

Apart from a joint call for global reform, Zuma integrated South Africa's national development objectives and African agenda on BRICS commitments during the Summit held in Durban in 2013 (Mazenda 2016b; Asuelime 2018b). It is within this context that, the BRICS NDB granted the South African power utility, Eskom, a loan accounted to $\$ 811$ million in 2016. South Africa is envisaged to establish transmission lines to connect 500 Megawatts renewable energy constructed by independent power producers on the national grid through the loan (Neethling 2017). In agreement, Naidu (2015) indicates that, South Africa's self-proclaimed gateway to Africa in the BRICS forum was negated by multilateral and bilateral engagements by its partners with the continent. But Zuma's administration lobbied BRICS partners to fund infrastructure and other sustainable development projects on the continent. A case in point is the establishment of NDB African Regional Centre in Johannesburg in 2017. As such, BRICS cooperation covers various areas including industrialisation and infrastructure development prioritised by South Africa's National Development Plan (NDP) vision 2030 (Asuelime 2018b). For the ANC, the formation of BRICS NDB provides an alternative resource to support poor countries. The establishment of such Bank complement South Africa's effort at pursuing African Renaissance and deepening South-South cooperation (Friedrich Ebert Stiftung 2017).

Beyond deepening bilateral ties with China, South Africa intensified trade with other BRICS countries (Onyekwena, Taiwo and Uneze 2014). As mentioned earlier, the 2007-2009 lingering global economic crisis spurred Zuma to seek 
new sources of growth to rescue the domestic economy. The Western economies were depreciated by these developments (ZiYang 2014). It was only the booming economies of China and India that could be alternative partners for the commodities exporting countries such as South Africa (Cilliers 2017). As cited by Asuelime (2018b: 131), Zuma accounts that South Africa's trade with other BRICS partners reached 70 percent in 2014. He went on to mention that South Africa's trade with other BRICS partners increased from R268 billion in 2011 to R382 billion in 2014.

For Zuma's administration, the inception of BRICS carried growth prospects for the country. But the South African economy was downgraded from 20142015 by rating agencies due to poor growth, huge government debt and trade deficit. These developments raise questions as to whether BRICS bloc benefit South Africa or other partners benefit at the expense of Tshwane (Asuelime 2018b). Despite South Africa's effort at deepening bilateral relations with other BRICS partners, its enterprises are not operating effectively in the latter countries' economies. Asuelime (2018b) suggests that business regulations might be amongst other factors that undercut the efforts of South African companies. In China for example, the centralised economy made it difficult for South African enterprises to operate in that country. The Doing Business report cited by Asuelime (2018b) view South Africa as opened for business than other BRICS partners. It ranks South Africa at number 41 on the globe relative to Russia at 92, China at 96 and Brazil at 116.

On African developments, South Africa and China also engage each other through FOCAC established in 2000. The two countries co-chaired FOCAC for a period of 2015-2018. Zuma's administration called for symmetrical trade and investment between the African continent and China. This was evidenced by the integration of the mineral beneficiation resolution in the commitments of FOCAC held in 2015. The Forum on China-Africa Cooperation Johannesburg Action Plan 2016-2018 avers that the two sides commit to cooperate in the exploitation of mineral resources and support joint development through energy and natural resources. China undertook to enhance the capacity of African countries to intensify the processing of energy, mineral and natural resources, and increase employment opportunities. Additionally, China and African countries commit to support their enterprises and financial institutions to facilitate a cooperation that is mutually beneficial. This include enhancing the capacity of 
African countries and equipping them with much needed technology through technology transfer to facilitate mineral beneficiation. Thus, China is committed to aid African countries in their quest to attain socio-economic development by transforming energy and mineral resources through local companies (FOCAC 2015). South Africa also pushed for the integration of environmental and labour standards in the 2015 FOCAC commitments (Naidu 2015). Under the auspices of FOCAC, South Africa and China engaged in African peacekeeping and peacemaking missions led by the African Union (AU) and UN.

\section{A Shift OR Priority? Zuma's Foreign Policy Towards China}

This section seeks to answer the question as to whether South Africa's growing ties with China under Zuma's presidency marked a shift in Tshwane's foreign policy or the latter country received an apex priority. By so doing, the section analyses South Africa's foreign policy towards China, from Mandela to Zuma's incumbency. Among others, it builds on the works of Alden and Wu (2014;2016), Landsberg (2010;2012), Cilliers (2017), Asuelime (2018), Anthony et al (2015), Dudley (2013), Grimm et al (2014), James and Mill (2016) and Onyekwena et al (2014). The other literature is drawn from the works of Shoba (2018), Soko and Qobo (2016), Neethling (2017), Langa and Shai (2019), Mpungose (2018), Qobo and Dube (2015) and the Department of International Relations and Cooperation Annual Report 2016/2017.

Mandela's delay to severe diplomatic relations with Taiwan and meetings he held with the Dalai Lama have affected South Africa's relationship with China (Gumede 2014; Anthony et al 2015). During Mbeki's tenure South Africa-China relationship was superficial. But there were key developments as evidenced by the signing of Bi-National Commission in 2001 and the upgrading of the relationship to Strategic Partnership in 2004 during the second Bi-National Commission. The latter development saw South Africa according China a market economic status (Mpungose 2018). Even though, China was not the apex priority to South Africa, and this was evidenced by Mbeki's delay to advance relations with China. For example, the Bi-National Commission and Strategic Partnership were signed after he has been in the office for two years (Alden and Wu 2016; Mpungose 2018).

Mbeki's foreign policy focused largely on the development of the African 
continent through initiatives such as the New Partnership for Africa's Development (NEPAD). He sought aid and investment from the then Group of Eight countries (G8) (now Group of Seven) (Alden and Wu 2014; Landsberg 2012; Cilliers 2017; Benyi 2017). As such, China was to a large extent neglected under Mbeki's administration. Even in the face of the growing China-Africa relations under the auspices of FOCAC, Beijing did not receive much attention under Mbeki's incumbency. The nature of the then relationship is demonstrated by the developments such as the 2005 G8-Africa Summit wherein China received an invitation to participate at the last minutes (Alden and Wu 2016). From these developments, it could be inferred that China was not prioritised by Mbeki's administration. In agreement, Cilliers (2017:4) states that "China was, for Mbeki, still largely a sideshow”. Equally, Grimm et al (2014) submit that China and other Asian countries did not receive apex priority in Tshwane's foreign policy during Mandela and Mbeki's administrations. It was only after the leadership transition from Mbeki to Zuma, that Asian region particularly China received priority in South Africa's foreign policy.

While there was a cordial relationship between China and South Africa, Mbeki appeared to have misgivings about Beijing's engagement with the continent. In his speech at the South African Students Congress (SASCO) rally in 2006, Mbeki warned African continent about being the source of raw materials in exchange for Chinese value-added manufactured goods (Benyi 2017). The relationship was further complicated by issues pertaining to peace and security on the African continent as well as competition between the South African enterprises with their Chinese counterparts. Example in this regard, is South Africa's diverge view to China's support towards Sudan during the conflict in Darfur (Alden and Wu 2016). On issues pertaining to South-South cooperation and the reform of the United Nations Security Council (UNSC), Mbeki utilised IBSA (India, Brazil and South Africa) forum which excludes China (Cilliers 2017).

Alden and Wu (2016) indicate that there are schisms amongst South Africans about their country's relations with China. They demonstrate that to some scholars the relationship prompts a shift from the foreign policy informed by Western human rights values to the one guided by the developmental pragmatism of the non-democratic People's Republic of China (PRC). In their work entitled South Africa's changing foreign policy in a multi-polar world: The influence of China and other emerging powers, Anthony et al (2015) state that Zuma embraced relations 
with developing countries and the deepening of the African agenda. His foreign policy valued economic relations with developing and emerging countries, and this was implemented through the BRICS bloc. They went on to state that to some scholars, Russia and China, influenced South Africa's voting patterns in the UNSC.

Among other developments, in 2012 South Africa abstained in a vote meant to extend the United Nations Supervision Mission in Syria (UNSMIS). Voting on the same issue, China and Russia vetoed the Resolution. Again in 2014, South Africa along with other BRICS countries abstained from a motion condemning the Russia's military intervention in Ukraine. While he had visited South Africa in 1996, 1999 and 2004 respectively, the Dalai Lama was denied a visa by Zuma's administration in 2009, 2011 and 2014. Such decision to some scholars, media, opposition parties, civil society and members of the public, manifests that South Africa sold its sovereignty and is beholden to China (Anthony et al 2015; Dudley 2013; Valjalo 2018). China is a good partner to be aligned with given its economic clout, but the relationship appeared to deepen at the expense of South Africa's sovereignty. With the growing South Africa-China relations, the former country heeds to the influence of the latter (Qobo and Dube 2015). However, the contribution made by the West in South Africa's voting behavior particularly their abuse of the UNSC as manifested by the ousting and assassination of the former and late Libyan President, Muammar Gaddafi should not be overlooked.

Equally, Shoba (2018) asserts that the year 2009 ushered in a paradigm shift in South Africa's foreign policy from North to South. Zuma's administration has since the global economic crisis deepened relations with China and other emerging countries. His ascendancy was marked by high engagements with China and other BRICS partners. The country's admiration of China was shown by the actions it took in the international community (IC) which were in line with the wishes of Beijing. In his study entitled The Cons of South Africa's Membership in a China-led BRICS: An Appraisal, Asuelime (2018a) notes that China controls its BRICS partners in some areas. He went on to states that the Dalai Lama issue demonstrates South Africa's conformity to China. Another incident projecting that Tshwane is selling its identity is the announcement made by the South African Department of Basic Education (DoBE) in 2015 to offer Mandarin as a second additional official language in public schools. The move was questioned as South Africa cannot even teach its official languages. In 
the context of Afrocentricity, this move perpetuates cultural disorientation. In agreement, Moinogu (2015) affirms that China's cultural diplomacy is binding on states that seeks to deepen relations with Beijing.

To Zuma's led ANC, China served as an alternative to Western countries. He himself Zuma, quoted by Anthony et al (2015) says that "China offers an opportunity to African countries to be able to free themselves from the shackles that are really colonially designed". While with Europe, Africans are regarded as 'either a former subject or a second third class kind of a person', with China 'we relate as brothers and sisters to do business together, not because one is a poor cousin". Arguing on the same issue, the 2015 ANC National Council (NGC) discussion document cited by Anthony et al (2015), projects China as an alternative partner to South Africa rather than the United States. The document cites China's rapid economic growth as gradually transforming the unitary world to multipolar and went on to states that CCP should serve as an example to the ANC (Friedrich Ebert Stiftung 2017). Inferring from the document, Anthony et al (2015) states that ANC admired the Chinese economic development model and CCP leaders. They further state that such admiration spurred Zuma's government to formalise a shift from the United States in favour of China.

Similarly, James and Mills (2016) state that Zuma's administration sought to deepen its place in the ideological 'South' by moving away from traditional trade and investment partners, a move that produced little in terms of investment and job creation. In the same line of arguments, Cilliers (2017) underscores that Zuma's presidency turned things upside down in South Africa's foreign policy. Despite having history with the African continent, Western countries received scant attention in South Africa's foreign policy. Example in this regard, was Zuma's replacement of the Group of Seven (G7) countries with the BRIC (Brazil, Russia, India and China) bloc to support African development. He further states that these developments have far-reaching implications for South Africa's global reform agenda particularly the reform of the UNSC championed by the IBSA forum. In agreement Qobo and Dube (2015) remark that BRICS has downplayed the IBSA championed by Mbeki, a formation that was pertinent to push for the reform of the UNSC as its signatories are all non-permanent members to the Council.

Neethling (2017) expresses the same view that Zuma's foreign policy moved away from deepening relations with Western countries in favour of developing 
countries of Asia and Latin America. This was evidenced by its proximity towards BRICS and anti-Western sentiments. The ANC-led government has since 2009 gravitated towards BRICS to find an alternative development partners, particularly China. Quoted in (Neethling 2017: 43), Gerrit Olivier scathed South Africa's foreign policy as 'blinkered obsession with ideology' and 'a contrived anti-Western scepticism. The diplomatic and trade relations with the Western Europe including the United States declined. With regard to the United States, the tensions broke out in 2015 over the inflow of poultry from the United States which posed threats to the domestic markets. As a result, United States threatened to revoke the duty-free access of certain South African exports implemented under the Africa Growth and Opportunity Act (AGOA) (Mpungose 2018).

Conversely, Langa and Shai (2019) assert that South Africa's foreign policy remained the same under Zuma's administration. It is only the priorities that have changed. Among others, the promotion of human rights came second to South Africa's commitment to deepening South-South cooperation and promoting the African agenda. Arguing on the same issue, Landsberg (2012) notes that the leadership transition from Mbeki to Zuma did not lead to a change in foreign policy. The changes were only in leadership style and improvements in some areas, but the substance of foreign policy remained the same. During his inauguration in 2009, Zuma indicated that South Africa's foreign policy would not change. Zuma's administration employed different labels rather than necessarily changing the substance of South Africa's foreign policy

The deepening of South-South cooperation articulated by Mbeki's administration was echoed during Zuma's tenure (Benyi 2017). For Zuma's administration, South-South cooperation focused largely on deepening relations with India, China and Brazil. Zuma's administration also commits to exploit the role played by Mbeki in IBSA, New Asia-Africa Strategic Partnership (NAASP), Non-Alignment Movement (NAM) and the Group of Seventy-Seven Plus China (G77+China). But such efforts were undercut by the disengagement of the Latin American, Caribbean and Asian countries in some of these institutions (Landsberg 2010). His government continued with the country's commitment to partake in global governance and a call for global reform. It believed that the reform of global governance will improve African representation and address the continent myriad challenges (Landsberg 2012). In agreement, Langa and Shai (2019) state that,Zuma's administration regards the existing global governance as 
being outdated, hence unable to address challenges of the contemporary world.

In the same line of arguments, Mpungose (2018) submits that Zuma deepened ties with China and sustained a call for the reform of global governance architecture, notably, the World Trade Organisation (WTO) and UNSC. Equally, Asuelime (2018a) asserts that South Africa intensified ties with BRICS as part of its foreign policy objectives of deepening relations with emerging economies and developing countries. Thus, South Africa together with other BRICS partners called for the reform of the UNSC. They cite the UNSC ruling over a number of human rights cases in Africa, as a justification to include a representative from the continent (Anthony et al 2015).

Zuma's government continued with a commitment made by previous administrations to engage Northern industrialised powers and their associations (Landsberg 2012). Equally to his predecessors, Zuma lobbied developed countries to support development on the African continent and other developing countries. Landsberg (2012) cites the former Minister of International Relations and Cooperation Maite Nkoana-Mashabane saying that, developed countries are major economies on the globe critical for growth of developing countries. The Minister further says that South Africa seeks to form partnership with these countries to facilitate trade and development cooperation. The development aid drawn from developed countries was also meant to support South Africa's development.

President Jacob Zuma Cited by Besada, Tok and Winters (2013), accounts that South Africa's accession to BRICS does not suggests that developed countries are less significant. Arguing on the same issue, the Department of International Relations and Cooperation 2016/2017 Annual Report indicates that the Western Europe remains a key strategic region to South Africa and a source of foreign direct investment (FDI). The country's trade with that region stood at $25 \%$ in 2016, recorded an increase of 9 percent. The South African Reserve Bank cited in the same report shows that the European countries trade with South Africa stood at 76,5\%, accounted to R1 507 billion, while South Africa's trade with that region stood at 30.1\%, accounted to R723 billion. Trade between South Africa and European Union rose from R150 billion in 2000 to R588 billion in 2016, recorded an increase of 292\% (DIRCO 2017).

Inferring from the foregoing arguments, the author of this article argues that, Zuma's ascendancy did not mark a shift of South Africa's foreign policy from the 
West towards China. His incumbency builds on the international dynamics such as the rise of the East and decline of the Western economies during the global economic crisis. As a result, countries of the East particularly China received an apex priority in Zuma's foreign policy. In this regard, Zuma builds on South Africa's foreign policy principles of deepening South-South Cooperation to deepen ties with China. This should be understood in the context that; South Africa's foreign policy remains the same irrespective of incumbent President. It is only in the implementation process that certain pillars take precedence to others. As such, the views that Zuma's administration ushered in a shift in South Africa's foreign policy should be dismissed as the promotion of what NdlovuGatsheni (2014) called "global coloniality". The latter refers to the contemporary power patterns that are largely premised on coloniality wherein Western nations occupy an apex position while countries of the South including South Africa are consigned on the margins of the globe. In other words, coloniality refers to the continuation of colonial socio-economic, political and cultural patterns (Ndlovu-Gatsheni 2014). Thus, the views that Zuma introduced a policy shift from the West are largely informed by Eurocentric misconception of South Africa as a colonial subject rather than a sovereign state entitled to outright independence in policymaking and implementation. They indirectly suggest that South African policy implementation should be premised on the Western interests, wishes and preferences.

\section{Conclusion}

This article adds to the academic discourse on Zuma's foreign policy towards China by using Afrocentricity as an alternative theoretical framework to establish whether South Africa's deepening relations with China under Zuma's administration, led to a shift in Tshwane's foreign policy or the latter country was prioritised. The article established that, the deepening of South Africa-China relations did not lead to a shift into the former country's foreign policy. Guided by South Africa's commitment to South-South cooperation and the international dynamics brought by the global economic crisis, Zuma prioritised relations with China and other countries of the South. This should be understood in the context that South Africa's foreign policy remains the same irrespective of incumbent President. It is only in the implementation 
process that certain pillars take precedence to others. The views that Zuma's administration brought a shift in South Africa's foreign policy seeks to challenge global coloniality through which the Western countries occupy an apex position, while their Southern counterparts are consigned to the margins of the globe. These views are informed by the Eurocentric misconception of South Africa as a colonial subject rather than a sovereign state entitled to outright independence in policymaking and implementation. They indirectly suggest that South African policy implementation should be premised on the Western interests, wishes and preferences.

Acknowledgements: I am indebted to Shoki Mogofe for proofreading my work. 


\section{References}

Alden, C and YS Wu (2014), "South Africa and China: The Making of a Partnership. Global Powers and African Programme", Occasional Paper No 199. Johannesburg: South African Institute of International Affairs.

Alden, C and YS Wu (2016), "South African foreign policy and China: converging, competing interests, contested identities", Commonwealth and Comparative Politics, Vol 54, No 22, pp 203-231.

Anthony, R, Tembe, P and O Gull (2015), "South Africa's changing foreign policy in a multi-polar world: The influence of China and other emerging powers. Centre for Chinese Studies, Stellenbosch University”. (Available at: https:// scholar.sun.ac.za/handle/10019.1/98930, accessed 03 March 2020.)

Asante, MK (2007), An Afrocentric Manifesto: Toward an African Renaissance. Cambridge: Polity Press.

Asuelime, LE (2018a), "The Cons of South Africa's Membership in a China-led BRICS: An Appraisal,"Journal of African Union Studies, Vol 7, No 1, pp 115-128. Asuelime, LE (2018b), "The Pros of South Africa's Membership of BRICS: A Reappraisal", Journal of African Union Studies, Vol 7, No 1, pp 129-150.

Benyi, KA (2017), "The Effects of the Rise of China on the Political Economy of Africa: The Case of South Africa". MA Dissertation. Thohoyandou: University of Venda.

Besada,H; Tok,E and K Winters (2013), "South Africa in the BRICS: Opportunities, Challenges and Prospects", Africa Insight, Vol 42, No 4, pp 1-15.

Chiyemura, F (2014), "South Africa in BRICS: Prospects and Constraints". MA Dissertation. Johannesburg: University of Witwatersrand.

Cilliers, J (2017), "Life beyond BRICS? South Africa's future foreign policy interests". Southern Africa Report No 9. Institute for Security Studies. (Available at: https://issafrica.org/research/southern-africa-report/life-beyondbrics-south-africas-future-foreign-policy-interests, accessed 06 March 2020.)

DIRCO, (2017), "A better South Africa, A better Africa, A better World. Annual Report 2016/17. Department of International Relations”. (Available at: https://nationalgovernment.co.za/department-annual/186/2017-department:international-relations-and-cooperation-(dirco)-annual-report.pdf, accessed 09 March 2020.)

Dudley, A (2013), "South Africa's Foreign Policy: Striving towards Mandela's 
Ideals. Policy brief No 89. African Institute of South Africa”. (Available at: https:// www.ai.org.za/wp-content/uploads/downloads/2013/07/SouthAfricas-foreing-policy-Striving-towards-Mandelas-Ideals.pdf, accessed 06 March 2020.)

FOCAC (2015), "The Forum on China-Africa Cooperation Johannesburg Action Plan (2016-2018)”. (Available at: https:// www.focac.org/eng/zywx_1/zywj/ t1327961.htm, accessed 13 September 2020.)

Friedrich Ebert Stiftung (2017), "Foreign Policy Academic Sector Discussion Summary and Addendum Submission for the 5th National Policy Conference, July: An Assessment of the ANC's International Relations Discussion Document Towards the 5th National Policy Conference". (Available at: https:// www.fes-southafrica.org/fileadmin/user-upload/documents/SubmissionNPC-IR-2017.pdf, accessed 06 March 2020.)

Grimm, S; Kim, Y; Anthony, R; Attwell, R and X Xiao (2014), "South African relations with China and Taiwan Economic Realism and the 'One-China' Doctrine. Centre for Chinese Studies, Stellenbosch University”. (Available at: https://scholar.sun.ac.za/handle/10019.1/98937, accessed 03 March 2020.)

Gumede, W (2014), “The BRICS Alliance: Challenges and Opportunities for South Africa and Africa, Shifting Power-Critical Perspective on Emerging Economies, Transnational Institution Working Papers”. (Available at: https:// scholar.google.com/scholar?start=10\&q=William+Gumede $\&$ hl=en\&as$s \mathrm{dt}=0,5 \# \mathrm{~d}=$ gs-qabs\&u=023p\%3DEQXmZVos1I8J, accessed 19 April 2020. )

James, W and G Mills (2016), "Resetting South Africa's Foreign Policy”. (Available at: https://www.politicsweb.co.za/archive/resetting-south-africas-foreignpolicy, accessed 03 March 2020.)

Jing, H and F Zhongping (2014), "China's Strategic partnership diplomacy: engaging with a changing world. The Global Partnership Grid Series”. (Available at: https://papers.ssrn.com/sol3/papers.cfm?abstract_id=2459948, accessed 13 September 2020.)

Landsberg, C (2010), "The Foreign Policy of the Zuma Government: Pursuing the 'National Interest'?, South African Journal of International Affairs, Vol 17, No 3, pp 273-293.

Landsberg, C (2012), "Continuity and Change in the Foreign Policies of the Mbeki and Zuma Governments”, Africa Insight, Vol 41, No 4, pp 1-16.

Langa N and KB Shai (2019), “The Pillars of the Jacob Zuma-led South Africa's 
Foreign Policy: Afrocentric Review", African Renaissance, Vol 16, No 3, pp 107124.

Marthoz, JP (2012), "The Challenges and ambiguities of South Africa's foreign policy. NOREF Report”. (Available at: https:/www.files.ethz.ch/ isn/153069/1d25c9, accessed 03 March 2020.)

Mazama, A (2001), “The Afrocentric Paradigm Contours and Definitions”,Journal of Black Studies, Vol 31, No 4, pp 387-405.

Mazenda, A (2016a), "Development of BRICS Bilateral Trade Relations: A South African Perspective", Nile Journal of Business and Economics, No 2, pp 17-32.

Mazenda, A (2016b), "The Effect of BRICS Trade Relations on South Africa's Economic Growth". PHD Thesis. Alice: University of Fort Hare.

Mhaka, S and L Jeke (2018), "An Evaluation of the Trade Relationships between South Africa and China: An Empirical Review 1995-2014", South African Journal of Economic and Management Sciences, Vol 21, No 1, pp 1-15.

Mkabela, Q (2005), "Using the Afrocentric Method in Researching Indigenous African Culture", Qualitative Report, Vol 10, No 1, pp 178-189.

Moinogu, P (2015), "China South Africa Relations: Examining Gains and Hidden Challenges in Economic and Diplomatic Relations”. MA Dissertation. Durban: University of Kwazulu-Natal.

Monareng, LC (2016), "China-South Africa: A Comprehensive Strategic Partnership”. (Available at: https://www.researchgate.net/ publication/301732224-China-South-Africa-A-Comprehensive-StrategicPartnership, accessed 03 March 2020.)

Mpungose, L (2018), "South Africa's foreign policy under Zuma: towards strategic partnerships”. (Available at: https://saiia.org.za/research/south-africas-foreign-policy-under-zuma-towards-greater-strategic-partnerships/, accessed 10 March 2020.)

Naidu, S (2015), "South Africa and FOCAC: Enabling a Partnership for Global Economic Governance Beyond the BRICS? Economic Diplomacy Programme”, Policy Insights No 26. South African Institute of International Affairs.

Ndlovu-Gatsheni, SJ (2014), "Global Coloniality and the Challenges of Creating African Futures”, Strategic Review for Southern Africa, Vol 36, No 2, pp 181202.

Neethling, T (2017), "South Africa's Foreign Policy and the BRICS Formation: Reflections on the Quest for the 'Right' Economic-diplomatic Strategy”, Insight 
on Africa, Vol 9, No 1, pp 39-61.

Notshulwana, M (2012) "South Africa's National interest and BRICS: Towards Bandwagoning or Balancing?", Policy Brief No 4. Development Bank of Southern Africa.

Ntseane, PG (2011), "Culturally Sensitive Transformational Learning: Incorporating the Afrocentric Paradigm and African Feminism”, Adult Education Quarterly, Vol 61, No 4, pp 307-323.

Onyekwena, C, Taiwo, O and E Uneze (2014), "South Africa in BRICS: A Bilateral Trade Analysis. Economic Diplomacy Programme”, Occasional Paper No 127. South African Institute of International Affairs.

Qobo, M and M Dube (2015), "South Africa's Foreign Economic Strategies in a Changing Global System", South African Journal of International Affairs, Vol 22, No 2, pp 145-164.

Reviere, R (2001), "Toward an Afrocentric Research Methodology", Journal of Black Studies, Vol 31, No 6, pp 709-728.

Schreiber, L (2000), "Overcoming Methodological Elitism: Afrocentrism as a Prototypical Paradigm for Intercultural Research”, International Journal of Intercultural Relations, Vol 24, No 5, pp 651-671.

Shai, KB (2016), "An Afrocentric Critique of the United States of America's Foreign Policy towards Africa: The Case Studies of Ghana and Tanzania, 19902014”. PHD Thesis. Mankweng: University of Limpopo.

Shoba, MS (2018), "South Africa's Foreign Policy Position in BRICS", Journal of African Union Studies, Vol 7, No 1, pp 173-188.

Soko, M and M Qobo (2016), "The Role of the BRIC in Africa's Development: Drivers and Strategies", Journal for Contemporary History, Vol 41, No 1, pp 80102.

Tshetlo, PT and G Naidoo (2015), "An analysis of the Implementation of the SAChina Bilateral Agreement: The Case Study of the South African Agricultural Technology Demonstration Centre (SAATDC)", African Journal of Public Affairs, Vol 8, No 2, pp 104-119.

Valjalo, TF (2018) "Is South Africa Worthy of IT's BRIC in BRICS?" MA Dissertation. University of South Africa.

Yong, W (2012), "South Africa's Role in the BRICS and the G-20: China's View". Economic Diplomacy Programme Occasional Paper No 127. Johannesburg: South African Institute of International Affairs. 
Yu, M (2018), "Two Sets of Truths? A Content Analysis of South African Media Coverage of China during the FOCAC 2015 Johannesburg Summit”. MA Thesis. Johannesburg: University of the Witwatersrand.

ZiYang, M (2014), “The Impact of the Emergence of China's Economy on South Africa”. MA Dissertation. Québec: University of Laval. 